\title{
Knowledge, attitude and practice of municipal solid waste management among highland residents in Northern Thailand
}

Anuttara Hongtong

Environmental Health Program, School of Health Science, Mae Fah Luang University, Chiang Rai, Thailand

Tawatchai Apidechkul

Center of Excellence for the Hill-tribe Health Research, Mae Fah Luang University, Chiang Rai, Thailand, and

Nittaya Pasukphun

Environmental Health Program, School of Health Science, Mae Fah Luang University, Chiang Rai, Thailand

\begin{abstract}
Purpose - Chiang Rai is the northernmost province of Thailand. Municipal solid wastes (MSWs) was generated 430,828.2 ton/y in this area; however, only 24 percent of waste was properly disposed, and 43 percent of waste was properly managed. The purpose of this paper is to explore knowledge, attitudes and practices (KAP) of highland residents in order to provide a basis for the development of waste management in the study area.

Design/methodology/approach - A cross-sectional study was conducted in Mae Fah Luang district, Thailand, from November 2016 to January 2017. A random sample of 451 respondents constituted the study population. Data were gathered using a structured questionnaire. Pearson Correlation and $\chi^{2}$ were applied to identify the association among variables.

Findings - Overall, 73 percent of respondents had high level of knowledge; 85 percent of respondents showed neutral attitude; and 59 percent of respondents performed moderate practice on MSW management. The results highlighted that age and education levels were statistically significant associated with KAP levels on MSW management at $(p=0.05)$.

Originality/value - The respondents who have good knowledge also have a good level of practice; and those who have good attitude also have a good level of practice. Socio-demographic factors and suitable way to promote an effective MSW management should be considered.
\end{abstract}

Keywords Knowledge, Questionnaire survey, Attitude and practice, Municipal solid waste management, Highland residents

Paper type Research paper

(C) Pussadee Laor, Yanasinee Suma, Vivat Keawdounglek, Anuttara Hongtong, Tawatchai Apidechkul and Nittaya Pasukphun. Published in the Journal of Health Research. Published by Emerald Publishing Limited. This article is published under the Creative Commons Attribution (CC BY 4.0) licence. Anyone may reproduce, distribute, translate and create derivative works of this article (for both commercial \& non-commercial purposes), subject to full attribution to the original publication and authors. The full terms of this licence may be seen at http://creativecommons.org/licences/by/4.0/legalcode

The researchers would like to thank the participants for their cooperation and time. The authors would like to gratefully acknowledge the National Research Council of Thailand for supporting grant of this research.

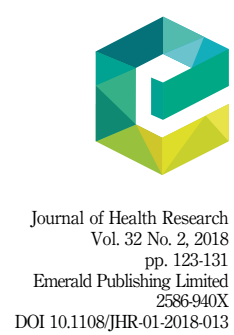


JHR

32,2

\section{Introduction}

Municipal solid wastes (MSW) are unwanted materials or wastes primarily generated from households and municipal services[1]. Thailand is one of the developing countries in Southeast Asia. The country has witnessed an accumulating problem of solid waste management and disposal[2]. The MSW generation rate of Thailand is at the typical range of $0.3-1.44 \mathrm{~kg} / \mathrm{capita} /$ day and with its average of $1.443 \mathrm{~kg} / \mathrm{capita} /$ day[3]. Unfortunately, only 52 percent (7.421 million tons) of the total volume of collected waste was properly managed. On the other hand, about 48 percent of total volume of collected waste was appropriately disposed such as open burring and open dumping[4]. Considering with increasing population, rapid development and urbanization, providing a suitable waste management involving the health problems is a challenging task in several communities. There are the numbers of developing countries which suffer significantly from these problems because garbage collection operations do not have enough or do not occur at all[5]. The reduction of waste generation is the best and most cost-effective method to solve these problems [6]. One of the appropriate approaches to reduce waste generation is to promote MSW separation and recycling. Therefore, people play an important role in MSW management including waste generation, source separation, storage, collection, recycling and disposal.

To achieve the successfulness of MSW management, there are not only the providing infrastructures by local government, but also understanding public concerns, knowledge and behavior[6]. In addition, the public participation on source separation process strongly affects the success of household recycling programs. For a better understanding on the mechanisms responsible for resident participation in the waste management programs, there is an important need to examine and fulfill theory-based detailed surveys. Various studies have been conducted on assessment of factors influencing these behaviors including knowledge, attitudes, and practices (KAP)[6].

Chiang Rai is the northernmost provinces of Thailand with the highland and lowland areas. Unfortunately, the Regional Environment Office 1 reported that MSWs was generated 430,828.2 ton/y, but only 24.4 percent of wastes were proper disposed; only 21 percent of wastes were re-utilized and 43.2 percent of wastes were not managed[7]. Furthermore, still more difficult for highland residents is the fact that MSW management includes waste separation, transportation and disposal because of the characteristic of topology (high-slope areas), small roads and the limitation of disposal area, and there are local hill-tribes scattering in highland area of Chiang Rai province. To achieve the successful of MSW management in highland is the challenge. Thus, the highland area of Chiang Rai province was selected as a model community in our study.

This study aimed at identifying KAP to provide a basis for development of waste management in highland community as a whole.

\section{Materials and methods}

Study design

A community based cross-sectional study design was used to find the KAP of the highland residents at the community level in Mae Fah Luang district, Chiang Rai province, Thailand, from November 2016 to January 2017.

\section{Study area}

The study was conducted in Mae Fah Luang district including Mae Salong Nai, Mae Salong Nok and Therd Thai sub-districts. Most of population of this district is made up of six or seven different hill-tribe racial groups: Mien, Lisu, Lahu, Hmong, Shan/Tai Yai, Chainese Yunan/Haw and Akha who inhabit the district[8]. Each group has their own language which is dissimilar from those of Thai indigenous people[9]. 
Study population was permanent highland residents in Mae Fah Luang district, Chiang Rai province, Thailand.

\section{Sample size estimation and sampling techniques}

The sample for this study was determined using the Yamane formula of 1967[10]. From the calculation, the 406 respondents were required. Sample size was calculated plus 10 percent for errors with the total of 451: Mae Salong Nai, 220 participants; Mae Salong Nok, 151 participants; and Therd Thai, 80 participants. Participants were selected randomly using the simple random sampling technique. They were interviewed using questionnaires. Participants, who were unable to speak Thai, were excluded from the study.

Data were collected by using questionnaires. A questionnaire, weighing scale and height taking scale were used as instruments for data collection. The questionnaire consisted of four different parts according to the type of data. The first part contained detailed information on demographics such as age, gender, status, education level, occupation, income, family size and types of houses. The subsequent second part was knowledge questions contained 15 questions; they were structured and close-ended where the maximum and minimum scores were "yes" and "no," respectively. The third part was attitude questionnaire. It covered ten questions, and they were structured and close-ended which set in a Likert scale with a maximum score of 3 (agree) and 1 (disagree) for positive statements and vice versa for negative statements. The fourth part was a practice questionnaire covering 15 questions. They were structured and close-ended which set in a Likert scale with a maximum score of 4 (often) and 1 (never). The validity was tested by three experts and adjusted using the item objective congruence (IOC) technique developed by Rovinelli and Hambleton in 1977[11]. The IOC technique was used for appropriate question identification. Questions were adjusted and corrected if the IOC value was found to be less than 0.50 . All of questions were tested for reliability by means of pilot-testing with 50 people in an area with similar characteristics as the study area. The reliability of knowledge questions were tested by KR20 and calculated as 0.60 . To examine the reliability of attitude and practice, the computed Cronbach's $\alpha$ s was 0.63 and 0.82, respectively. These values were deemed acceptable according to the standard scale.

\section{Data analysis}

Data were analyzed using SPSS version 20, 2014 (SPSS, Chicago, IL). General information was analyzed by the descriptive statistics. Actual counts, relative frequencies, means and standard derivation were used in the descriptive analysis to describe the characteristics of sample. To find factors associated with KAP, the descriptive statistics, Pearson correlation and $\chi^{2}$ model were used. All inferential statistics were achieved at the 95 percent confidence level.

\section{Ethical considerations}

All the research procedures had been approved by the School of Health Science, Mae Fah Luang University Research Ethics Committee on Human Research by No. 8/2558.

\section{Results}

\section{Socio-demographic characteristics of the respondents}

Out of the total of 451 samples, the majority of respondents were female (63.2 percent). Most (39.2 percent) of respondents were 20-40 years old, followed by $41-59$ years old (29.0 percent) and under 20 years old (22.6 percent). More than half of respondents were married, which accounted for 63.2 percent and followed by single status (31.5 percent). 
JHR

32,2

126

In total, 37.5 percent of respondents indicated that they had achieved a secondary school, and nearly 29.3 percent of respondents who had no education. Majority of respondents were merchants (33.0 percent) followed by private company employees (1.6 percent). Majority of the respondents (87.4 percent) reported that they lived in private house. Most (68.3 percent) of respondents had monthly income lower than 15,000 baht. More than half of the respondents (51.0 percent) has the family size of five to eight persons in their household. Most of the respondents received information about MSW from community leaders (42.6 percent), while only 25.1 percent of respondents did not received information as shown in Table I.

\section{KAP on MSW management}

The level of knowledge of respondents according to scores obtained. Among respondents, the maximum score was 15, and the minimum was 3 for knowledge on MSW management. There were 15 questions. The scores range from 12 to 15 scores, 8 to 11 scores and less than 8 scores. The result of each level showed high (73.4 percent), moderate (23.7 percent) and low levels (2.9 percent), respectively.

Regarding attitude on MSW management, there were ten questions to test attitude of respondents. Among respondents, the maximum score was 30, and the minimum was 13 for attitude on MSW management. The scores range from 26 to 30 scores, 20 to 25 scores and less than 18 scores. The result of each level showed positive (2.9 percent), neutral (85.1 percent) and negative levels (12.0 percent), respectively. In term of practices on MSW management, it was investigated by using 15 questions. Among respondents, the maximum score was 60 , and the minimum was 17 for practice on MSW management. The scores range from 46 to 60 scores, 32 to 45 scores and less than 32 scores. Result of each level showed good practice (23.3 percent), moderate practice (59.0 percent) and poor practice (17.7 percent), respectively, as shown in Table II.

\section{Association between KAP and socio-demographic characteristics of respondents}

Pearson's $\chi^{2}$ was used to find the association between socio-demographic characteristics and KAP of MSW management of respondents. As shown in Table III, it was observed that there was a significant association between each variable of socio-demographic and KAP of respondents.

All socio-demographic variables were statistically significant associated at 0.05 level, variables including age $(p=0.000)$, education level $(p=0.012)$ and occupation $(p=0.039)$ on MSW management.

The association between socio-demographic variables and attitude of respondents were tested on statistically significant at 0.05 level. It found age $(p=0.017)$, education level $(p=0.042)$ and community media online information source $(p=0.022)$ (Table IV).

Practice of respondent and socio-demographic variables were statistically significant associated at 0.05 level consisted of six variables including age $(p=0.001)$, marital status $(p=0.024)$, education level $(p=0.021)$, source of waste management's information (do not receive information, $p=0.001)$, community radio $(p=0.009)$ and local newspaper $(p=0.004)$. It indicated that these six variables were associated with practice (Table V).

Pearson " $r$ " correlation test was used to find the association between KAP regarding MSW management, and it was observed that there were a statistically significant associated between knowledge and practice with the correlation coefficient $0.187(p=0.000)$ at 0.01 level, and it showed significant positive correlation. The association between attitude and practice showed the correlation coefficient $0.253(p=0.000)$ at 0.01 level. It also showed a significant positive correlation. Knowledge and attitude were not found correlated with MSW management as shown in Table VI. Respondents who had good knowledge also had good level of practice, and those who had good attitude also had good practice level. 


\begin{tabular}{|c|c|c|c|}
\hline Characteristics & $n$ & $\%$ & Mlunicipal solid \\
\hline $\begin{array}{l}\text { Gender } \\
\text { Male } \\
\text { Female }\end{array}$ & $\begin{array}{l}165 \\
286\end{array}$ & $\begin{array}{l}36.6 \\
63.4\end{array}$ & management \\
\hline $\begin{array}{l}\text { Age (years) } \\
<20 \\
20-40 \\
41-59 \\
>60 \\
\text { Mean }=35.59, \mathrm{SD}=16.42\end{array}$ & $\begin{array}{r}102 \\
177 \\
131 \\
41\end{array}$ & $\begin{array}{r}22.6 \\
39.2 \\
29.0 \\
9.1\end{array}$ & 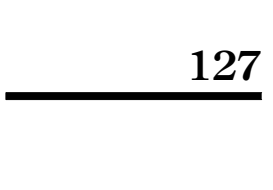 \\
\hline $\begin{array}{l}\text { Marital status } \\
\text { Single } \\
\text { Married } \\
\text { Divorce } \\
\text { Others }\end{array}$ & $\begin{array}{r}141 \\
283 \\
13 \\
11\end{array}$ & $\begin{array}{r}31.5 \\
63.2 \\
2.9 \\
2.5\end{array}$ & \\
\hline $\begin{array}{l}\text { Education level } \\
\text { No education } \\
\text { Primary school } \\
\text { Secondary school } \\
\text { Diploma } \\
\text { Bachelor's degree or higher }\end{array}$ & $\begin{array}{r}132 \\
70 \\
169 \\
24 \\
56\end{array}$ & $\begin{array}{r}29.3 \\
15.5 \\
37.5 \\
5.3 \\
12.4\end{array}$ & \\
\hline $\begin{array}{l}\text { Occupation } \\
\text { Unemployed } \\
\text { Farmer } \\
\text { Merchant } \\
\text { Company employees } \\
\text { Government employees } \\
\text { Housewife } \\
\text { Business owners } \\
\text { General contractors } \\
\text { Others }\end{array}$ & $\begin{array}{r}59 \\
32 \\
153 \\
7 \\
19 \\
17 \\
32 \\
62 \\
70\end{array}$ & $\begin{array}{r}13.1 \\
7.1 \\
33.9 \\
1.6 \\
4.2 \\
3.8 \\
7.1 \\
13.7 \\
15.5\end{array}$ & \\
\hline $\begin{array}{l}\text { Types of homes } \\
\text { House } \\
\text { Apartment } \\
\text { Townhouses } \\
\text { Others }\end{array}$ & $\begin{array}{r}394 \\
35 \\
8 \\
14\end{array}$ & $\begin{array}{r}87.4 \\
7.8 \\
1.8 \\
3.0\end{array}$ & \\
\hline $\begin{array}{l}\text { Monthly income (baht) } \\
<15,000 \\
15,000-33,000 \\
>33,000 \\
\text { Mean }=15,285.55, \mathrm{SD}=18,878.70\end{array}$ & $\begin{array}{r}244 \\
83 \\
30\end{array}$ & $\begin{array}{r}68.3 \\
23.2 \\
8.4\end{array}$ & \\
\hline $\begin{array}{l}\text { Number of household members } \\
1-4 \\
5-8 \\
>8 \\
\text { Mean }=4.92, \mathrm{SD}=2.01\end{array}$ & $\begin{array}{r}202 \\
230 \\
19\end{array}$ & $\begin{array}{r}44.8 \\
51.0 \\
4.2\end{array}$ & \\
\hline $\begin{array}{l}\text { Source of waste management's inf } \\
\text { Do not receive information } \\
\text { Brochures } \\
\text { Community radio } \\
\text { Community media online } \\
\text { Local newspaper } \\
\text { Community leader } \\
\text { Others }\end{array}$ & $\begin{array}{r}113 \\
65 \\
89 \\
51 \\
11 \\
192 \\
38\end{array}$ & $\begin{array}{r}25.1 \\
14.4 \\
19.8 \\
11.3 \\
2.4 \\
42.6 \\
8.4\end{array}$ & $\begin{array}{r}\text { Table I. } \\
\text { Socio-demographic } \\
\text { characteristics of } \\
\text { respondents }\end{array}$ \\
\hline
\end{tabular}


Level of knowledge

High

Moderate

Low

Mean $=12.24, \mathrm{SD}=1.97$

$13(2.9)$

Mean $=21.89, \mathrm{SD}=2.12$

\section{Level of practice}

Table II.

Good
Knowledge $n(\%)$

\begin{tabular}{|c|c|c|c|c|}
\hline \multirow[b]{2}{*}{ Socio-demographic characteristics } & \multicolumn{4}{|c|}{ Knowledge $n(\%)$} \\
\hline & Low & Moderate & High & $p$-value \\
\hline \multicolumn{5}{|l|}{ Age (years) } \\
\hline$<20$ & $8(7.8)$ & $32(31.4)$ & $62(60.8)$ & $0.000^{*}$ \\
\hline $20-40$ & $1(0.6)$ & 32 (18.1) & $144(81.4)$ & \\
\hline $41-59$ & $3(2.3)$ & 27 (20.6) & $101(77.1)$ & \\
\hline$>60$ & $1(2.4)$ & $16(39.1)$ & $24(58.5)$ & \\
\hline \multicolumn{5}{|l|}{ Education level } \\
\hline No education & $7(5.3)$ & $38(28.8)$ & $87(65.9)$ & $0.012^{*}$ \\
\hline Primary school & $2(2.9)$ & 17 (24.3) & $51(72.9)$ & \\
\hline Secondary school & $4(2.4)$ & $45(26.6)$ & $120(71.0)$ & \\
\hline Diploma & $0(0.0)$ & $3(12.5)$ & $21(87.5)$ & \\
\hline Bachelor's degree or higher & $0(0.0)$ & $4(7.1)$ & $52(92.9)$ & \\
\hline \multicolumn{5}{|l|}{ Occupation } \\
\hline Unemployed & $2(3.4)$ & 18 (30.5) & $39(66.1)$ & $0.039 *$ \\
\hline Farmer & $0(0.0)$ & 7 (21.9) & $25(78.1)$ & \\
\hline Merchant & $6(3.9)$ & 33 (21.6) & 114 (74.5) & \\
\hline Company employees & $0(0.0)$ & $0(0.0)$ & $7(100.0)$ & \\
\hline Government employees & $0(0.0)$ & $1(5.3)$ & $18(94.7)$ & \\
\hline Housewife & $0(0.0)$ & $3(17.6)$ & $14(82.4)$ & \\
\hline Business owners & $0(0.0)$ & $3(9.4)$ & $29(90.6)$ & \\
\hline General contractors & $4(6.5)$ & $23(37.0)$ & $35(56.5)$ & \\
\hline Other & $1(1.4)$ & 19 (27.1) & $50(71.5)$ & \\
\hline Note: $*$ Significance level $\alpha=0.05$ & & & & \\
\hline
\end{tabular}

Table III.

Statistically significant association between sociodemographic characteristics and the level of knowledge on MSW management

\section{Discussion}

The finding of this research indicated that respondents had a high level of MSW management knowledge and the least positive attitude. Most of respondents had moderate level of practice on proper MSW management. The results showed that the relationship between socio-demographic characteristics and KAP of respondents were statistically significantly $(p<0.05)$. 


\begin{tabular}{|c|c|c|c|c|c|}
\hline \multirow[b]{2}{*}{ Socio-demographic characteristics } & \multirow[b]{2}{*}{ Negative } & \multicolumn{2}{|c|}{ Attitude $n(\%)$} & \multirow[b]{2}{*}{$p$-value } & Mlunicıpal solic \\
\hline & & Neutral & Positive & & waste \\
\hline \multicolumn{5}{|l|}{ Age (vears) } & ma \\
\hline$<20$ & $21(20.6)$ & $80(78.4)$ & $1(1.0)$ & $0.017^{*}$ & \\
\hline $20-40$ & 20 (11.3) & $152(85.9)$ & $5(2.8)$ & & \\
\hline $41-59$ & $8(6.1)$ & 119 (90.8) & $4(3.1)$ & & \\
\hline$>60$ & $5(12.2)$ & 33 (80.5) & $3(7.3)$ & & 129 \\
\hline \multicolumn{6}{|l|}{ Education level } \\
\hline No education & $23(17.4)$ & $103(78.0)$ & $6(4.5)$ & $0.042^{*}$ & \\
\hline Primary school & $8(11.4)$ & $61(87.2)$ & $1(1.4)$ & & Table IV. \\
\hline Secondary school & $21(12.4)$ & $142(84.0)$ & $6(3.6)$ & & Statistically \\
\hline Diploma & $1(4.2)$ & $23(95.8)$ & $0(0.0)$ & & significant association \\
\hline Bachelor's degree or higher & $1(1.8)$ & $55(98.2)$ & $0(0.0)$ & & between socio- \\
\hline \multirow{2}{*}{\multicolumn{2}{|c|}{$\begin{array}{l}\text { Source of waste management's information } \\
\text { Community media online }\end{array}$}} & & & & $\begin{array}{r}\text { demographic } \\
\text { characteristics and the }\end{array}$ \\
\hline & $1(2.0)$ & $50(98.0)$ & $0(0.0)$ & $0.022^{*}$ & level of attitude on \\
\hline \multicolumn{2}{|l|}{ Note: $*$ Significance level $\alpha=0.05$} & & & & MSW managemer \\
\hline
\end{tabular}

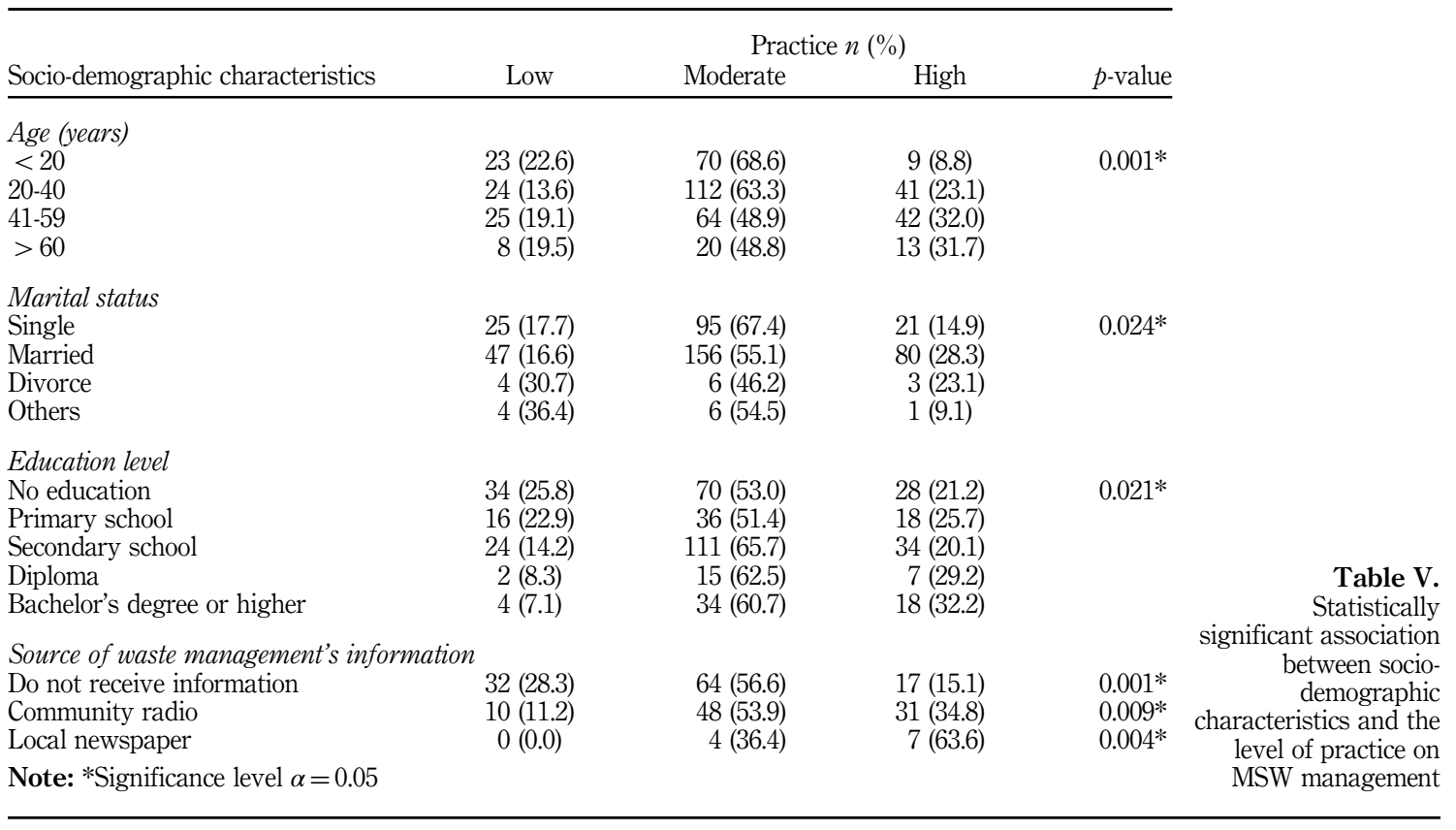

\begin{tabular}{|c|c|c|c|}
\hline Variables & $p$-value & Pearson's correlation $(r)$ & \\
\hline Knowledge and attitude & 0.065 & 0.087 & \\
\hline Knowledge and practice & 0.000 & $0.187 * *$ & Toblo VI \\
\hline Attitude and practice & 0.000 & $0.253 * *$ & $\begin{array}{l}\text { Table VI. } \\
\text { elation between }\end{array}$ \\
\hline \multicolumn{3}{|c|}{$\begin{array}{l}\text { Notes: Knowledge (mean }=12.24, \mathrm{SD}=1.97) \text {; attitude }(\text { mean }=21.89, \mathrm{SD}=2.12) \text {; practice (mean }=39.30 \text {, } \\
\mathrm{SD}=7.97) * * \text { Significant at the } 0.01 \text { level (two-tailed) }\end{array}$} & $\begin{array}{l}\text { KAP of respondents } \\
\text { on MSW management }\end{array}$ \\
\hline
\end{tabular}


JHR

32,2

In term of knowledge on MSW management, there were three demographic characteristics affected to the level of knowledge including age, education level and occupation. The result is similar to Garang et al.[12] and Laabar et al.[13]. A less-than-20-years-old group found that they had the highest percentage with low level of MSW management knowledge when compared with other age groups. In terms of the education factor, it noted that the highest percentage with low level of MSW management knowledge was a group of no education respondents when compared with other education groups. For occupation, it was found that the general contractors was a main group with low knowledge.

In term of attitude on MSW management, there were three demographic characteristics which affected to the level of attitude including age, education level and source of waste management's information. Based on the attitude influencing factors of the respondents, it was found that age and education levels were important factors; this is similar to the study of Panyako[14] and Barloa et al.[15], and the group of (less than 20 years old) with no education and secondary school level showed that they had more negative attitude than those of other groups. The community media online was statistically significant associated with the attitude level. It was an interesting factor to find out the suitable source of waste management information of respondents.

In term of practices, respondents were effected by four variables: age, marital status, education level and source of waste management information. Researchers found that the education level was affected to the practice level on MSW managements. The results of this study also supported these findings of Arora and Agarwal[16]. These results found that the respondents, who do not receive information, had a low practice level when compared with others. This study highlighted that the source of MSW information was very necessary to improve MSW management.

According to the correlation matrix of KAP on MSW management of respondents, it indicated that a practice level correlated with knowledge and attitude which is consistent with the study of Udomporn[6] and Barloa et al.[15]. These results indicated that knowledge and attitude had significant influence on MSW management. On the other hand, the association between knowledge and attitude found that there was no significant with Pearson's correlation $(r=0.087)$. The result is consistent to Arora and Agarwal[16].

\section{Conclusion}

The finding of this study indicated that participants' knowledge of MSW management is high, but the levels of attitude and practice are neutral and moderate, respectively. It showed positive correlation relationship between knowledge and practices. Furthermore, the result of this research was reasonably cleared that the most important issues must be focused on the group of young people (less than 20 years old). In this targeted group, they must receive adequate knowledge education on the waste management which directly affect their health and hygiene. Therefore, the local government should prioritize this group in order to promote knowledge and attitude on effective MSW management. In addition, the source of waste management's information is important in order to provide waste management information, and appropriate media should be selected for the target group.

\section{References}

1. Verma RL, Borongan G, Memon M. Municipal solid waste management in Ho Chi Minh City, Vietnam, current practices and future recommendation. Procedia Environ Sci. 2016; 35: (Suppl C): 127-39. doi: 10.1016/j.proenv.2016.07.059

2. Chiemchaisri C, Juanga JP, Visvanathan C. Municipal solid waste management in Thailand and disposal emission inventory. Environ Monit Assess. 2007 Dec; 135(1-3): 13-20. doi: 10.1007/s10661007-9707-1 
3. Troschinetz AM, Mihelcic JR. Sustainable recycling of municipal solid waste in developing Municipal solid countries. Waste Manag. 2009 Feb; 29(2): 915-23. doi: 10.1016/j.wasman.2008.04.016

4. Udomporn T. Resident's knowledge, attitude and practice towards solid waste management in Joho sub-district administrative organization, Mueang District, Nakhon Ratchasima, Thailand. Int J Eng Res Appl. 2015; (24): 13-6.

5. Ahmed SA, Ali SM. People as partners: facilitating people's participation in public-private partnerships for solid waste management. Habitat Int. 2006; 30(4): 781-96. doi: 10.1016/j. habitatint.2005.09.004

6. Babaei AA, Alavi N, Goudarzi G, Teymouri P, Ahmadi K, Rafiee M. Household recycling knowledge, attitudes and practices towards solid waste management. Resour Conser Recycl. 2015; 102: (Suppl C): 94-100. doi: 10.1016/j.resconrec.2015.06.014

7. Ministry of Natural Resources and Environment, Regional Environment Office 1. Annual environmental report 2015. [cited 2017 May 26]. Available from: www.reo01.mnre.go.th/ewt_dl_ link.php?nid $=465$

8. Duangtep Y, Narksawat K, Chongsuwat R, Rojanavipart P. Association between an unhealthy lifestyle and other factors with hypertension among hill tribe populations of Mae Fah Luang District, Chiang Rai Province, Thailand. Southeast Asian J Trop Med Public Health. 2010 May; 41(3): 726-34.

9. Apidechkul T, Laingoen O, Suwannaporn S. Inequity in accessing health care service in Thailand in 2015: a case study of the hill tribe people in Mae Fah Luang district, Chiang rai, Thailand. J Health Res. 2016; 30(1): 67-71.

10. Glenn D. Determining sample size. [cited 2017 January 14]. Available from: www.sut.ac.th/im/data/ read6.pdf

11. Apidechkul T, Pongwiriyakul S. Factors associated with HIV and HBV co-infection in Northern Thailand. Asian Pac J Trop Dis. 2016; 6(3): 174-8. doi: 10.1016/S2222-1808(15)61008-8

12. Garang MJ, Wilkister NM, Millicent AM. Assessment of the factors and challenges related to solid waste management in Bor Town, South Sudan. JNSR. 2016; 6(22): 1-6.

13. Laabar TD, Siriwang W, Robson M. Hospital waste management: a study on knowledge, attitude and practice among health staff and waste handlers in Jigme Dorji Wangchuk National Referral Hospital, Thimphu, Bhutan. J Health Res. 2012; 26(5): 271-5.

14. Panyako O, Wakhuhgu JW, Kioli FN. Demographic and socio-economic factors as determinant of environmental attitude in Mavoko Peri-Urban settlements of Nairobi Methropolis, Kenya. AJSSH. 2015; 3(3): 20-43.

15. Barloa EP, Lapie LP, de la Cruz CPP. Knowledge, attitudes, and practices on solid waste management among undergraduate students in a Philippine state university. JEES. 2016; 6(6): 146-53.

16. Arora L, Agarwal S. Knowledge, attitude and practices regarding waste management in selected hostel students of University of Rajasthan, Jaipur. IJCEPR. 2011; 2(1): 40-3.

\section{Corresponding author}

Nittaya Pasukphun can be contacted at: nittapsp@gmail.com

For instructions on how to order reprints of this article, please visit our website: 